\title{
Kolmivuotinen seurantakoe tukee lypsylehmien lisäfosforista luopumista
}

\author{
Samu Palander ${ }^{1)}$, Susanna Tauriainen ${ }^{2)}$, Pekka Huhtanen ${ }^{3)}$, Kirsi Suhonen ${ }^{1)}$, Eero Mäkäräinen ${ }^{4)}$ \\ ${ }^{1)}$ Seinäjoen ammattikorkeakoulu, Maa- ja metsätalouden yksikkö, Ilmajoentie 525, 60800 Ilmajoki, \\ samu.palander@seamk.fi \\ ${ }^{2)}$ Opetushallitus, PL 380, 00531 Helsinki, susanna.tauriainen@oph.fi \\ ${ }^{3)}$ MTT Eläinravitsemus, 31600 Jokioinen, pekka.huhtanen@mtt.fi \\ ${ }^{4)}$ Rehumelica, Kesäkuja 2 A, 02200 Espoo, eero.makarainen@rehumelica.fi
}

\section{Tiivistelmä}

Vuonna 2003 aloitettiin kolmivuotinen seurantatutkimus lypsylehmien matalamman fosforiruokintatason vaikutuksista. Suomalaisia lypsylehmien fosforiruokintasuosituksia muutettiin vuonna 2004. Muutosperusteena olivat kuitenkin ulkomaiset tutkimukset ja normit, eikä kotimaisia fosforiruokintatuloksia ole ollut käytettävissä. Lypsylehmien ruokinnassa on perinteisesti aina ollut fosforitäydennys. Periaatteessa nykyiset normit täyttävä fosforin saanti toteutuu kuitenkin tyypillisestä säilörehua, viljaa ja rypsirouhetta sisältävästä ruokinnasta. Selvitysten mukaan tilaolosuhteissa lypsylehmien kalsiumin, fosforin, magnesiumin ja kaliumin saanti ylittää huomattavasti vanhojenkin ruokintanormien tason. Voidaan olettaa meilläkin olevan varaa vähentää fosforiruokintaa ja näin ollen vähentää myös ympäristöön päätyvää fosforin määrää, etenkin kun on viitteitä siitä, että kivennäisrehun mukana annettu lisäfosfori on lannasta erityisen huuhtoutumisherkkää. Tämän tutkimuksen tavoitteena oli pitkäaikaiskokeella tutkia fosforittoman kivennäisrehun käytön vaikutuksia lypsylehmien maidontuotantoon, terveyteen, hedelmällisyyteen ja lannassa erittyvän fosforin määrään. Koe-eläiminä olivat Ilmajoen koulutilan lypsylehmät, ja kokeessa pyrittiin keräämään tietoja kaikilta kokeeseen tulevilta lehmiltä kolmen lypsykauden ajan. Eläimet oli jaettu kahdelle ruokintakäsittelylle: (1)fosforiton kivennäinen lypsäville lehmille ja ummessaoleville sekä sisä- että laidunruokintakaudella ja (2)tavanomainen, aikaisemmat suositukset täyttävä kivennäisruokinta. Muu rehustus oli samanlainen kaikille ja käsitti vapaan säilörehun (/laidunnnurmen) saannin ja vilja-rypsirouheseoksen tasaväkirehuruokinnan periaatteella. Kokeessa määritettiin karjantarkkailun mukaiset tuotos-, tiinehtymisja terveystiedot. Lisäksi lehmiltä otettiin verinäytteet (kaulalaskimosta) ennen koetta, 2-3 kk ja 7-8 kk poikimisesta ja sontanäytteet kahdesti sisä- ja ulkoruokintakauden aikana. Veriplasmasta analysoitiin fosfori-, kalsium ja magnesiumpitoisuudet ja sonnasta fosforipitoisuus. Keskimäärin ryhmän 1 lehmät lypsivät ensimmäisellä, toisella ja kolmannella tuotantokaudella (305 päivän tuotos) 6230, 7490, ja 7580 kg ja ryhmän 2 lehmät vastaavasti 6420,7460 ja $7140 \mathrm{~kg}$, mutta mitkään erot eivät olleet tilastollisesti merkitseviä. Myöskään valkuais-, rasva- ja solupitoisuuksissa ei ollut merkitseviä eroja. Siemennyksiä tiinehtymistä kohti on tarvittu ryhmissä 1 ja 2 keskimäärin 3,1 ja 2,6; poikimavälit olivat vastaavasti 403 ja 396 d mutta nämäkään erot eivät olleet tilastollisesti merkitseviä. Myöskään sorkkavikojen esiintymisessä ei ollut eroa. Lannan fosforipitoisuudessa sisä- ja ulkoruokintakaudella ryhmän 1 keskiarvot olivat 8,34 ja $11,03 \mathrm{~g} / \mathrm{kg}$ ka ja ryhmän 2 vastaavasti 9,20 ja $10,16 \mathrm{~g} / \mathrm{kg} \mathrm{ka}$. Kaikilla näytteenottokerroilla erot eivät olleet merkitseviä. Kokonaisuudessa fosforittomalla kivennäisellä ei ole ollut merkittävää vaikutusta lehmien tuotokseen, terveyteen tai hedelmällisyyteen.

\section{Asiasanat}

lypsylehmä, fosfori, ruokintasusoitukset, maidontuotanto, terveys 


\section{Johdanto}

Lypsylehmien ruokinnassa on perinteisesti aina ollut fosforitäydennys, ja fosforia sisältävää kivennäisrehua on käytetty sekä ummessaolo- että lypsykaudella. Suomalaiset lypsylehmien kivennäistarvenormit perustuivat aiemmin englantilaisiin 1960-luvulla laadittuihin normeihin, ja niissä fosforiruokinnan taso oli noin 4,5 g rehun kuiva-ainekiloa kohden (Tuori ym. 1996). Kuitenkin viimeaikaisissa amerikkalaisissa tutkimuksissa on päädytty suosittelemaan 3,5 $\mathrm{g}$ fosforia rehun kuivaainekiloa kohti (Wu ym. 2001).

Mitä ilmeisimmin meilläkin on varaa vähentää fosforiruokintaa ja näin ollen vähentää myös ympäristöön, pellolle päätyvää fosforin määrää. Viljavuuspalvelun tilastojen mukaan Suomessa peltojen fosforikuormitus on koko ajan lisääntynyt 1950-luvulta lähtien. Lisäksi fosforin yliruokinta on ollut vanhojenkin normien suhteen Yrjäsen ym. (2003) mukaan hyvin yleistä. Tässä esiteltävä tutkimus on aloitettu vuonna 2003, mutta suomalaisia fosforiruokintasuosituksia muutettiin niukemmiksi vuonna 2004 (MTT 2004). Tässä muutoksessa perusteena olivat kuitenkin ulkomaiset tutkimukset ja normit, eikä kotimaisia fosforiruokintatuloksia ole ollut käytettävissä. Kotimaisilla tutkimuslaitoksilla ei ole mahdollisuutta sitoa lypsykarjakapasiteettiaan tämäntyyppiseen seurantatutkimukseen.

Suuri osa lypsylehmien fosforin saannista on peräisin maitotuotosta lisäävistä, taloudellisesti perusteltavista tekijöistä, kuten valkuaisrehujen käytöstä (Yrjänen ym. 2003). Periaatteessa nykyiset normit täyttävä fosforin saanti toteutuu tyypillisestä säilörehua, viljaa ja rypsirouhetta sisältävästä ruokinnasta, eikä fosforia tarvitsisi lisätä lehmien kivennäisrehuseoksiin. Tämän tutkimuksen tavoitteena on ollut pitkäaikaiskokeella tutkia fosforittoman kivennäisrehun käytön vaikutuksia lypsylehmien maidontuotantoon, terveyteen, hedelmällisyyteen ja lannassa erittyvän fosforin määrään. Tutkimuksessa kerättiin tietoja kaikilta kokeeseen tulleilta lehmiltä keskimäärin kolmen lypsykauden ajan. Tutkimuksen kokeellinen osa Ilmajoen tutkimus- ja koulutilan navetassa päättyi vuoden 2006 lopussa.

\section{Aineisto ja menetelmät}

Koe-eläiminä ovat olleet Ilmajoen tutkimus- ja koulutilan noin kolmekymmentä lypsylehmää, joita hoidettiin pihattonavetassa normaalien hoitokäytäntöjen mukaisesti sekä käytettiin samanaikaisesti opetuksessa. Lehmät oli jaettu kahdelle ruokintakäsittelylle:

1. ryhmä: fosforiton kivennäisrehuseos lypsäville lehmille ja ummessaoleville sekä sisä- että laidunruokintakaudella

2. ryhmä: tavanomainen, aikaisemmat suositukset täyttävä kivennäisruokinta.

Muuten rehustus oli samanlainen molemmille ryhmille ja perustui säilörehuun, ohra-kauraseokseen (1:1) ja rypsirouheeseen. Käytössä oli lähinnä tasaväkirehuruokinnan periaatetta noudattava ruokintamalli. Säilörehua oli tarjolla vapaasti, ja yksilöllisen väkirehu- ja kivennäisrehuannoksensa lehmät saivat ryhmänsä mukaisesta väkirehukioskista.

Lehmiltä määritettiin ja kirjattiin lähinnä karjantarkkailun mukaiset tuotos-, tiinehtymis- ja terveystiedot. Käytössä olleista väkirehuista kerättiin näytteitä 3-4 kertaa ruokintakauden aikana.

Lisäksi lehmiltä otettiin verinäytteet kaulalaskimosta ennen koetta (0-näyte), korkean tuotannon vaiheessa $(2-3 \mathrm{kk}$ poikimisesta $) \mathrm{ja}$ matalamman tuotannon vaiheessa $(7-8 \mathrm{kk}$ poikimisesta).Verinäytteet jäähdytettiin välittömästi jäävesihauteessa ja sentrifugoitiin plasman erottamiseksi. Sontanäytteet otettiin kahtena vuonna sisä- ja ulkoruokintakausien aikana tutkimuksessa olevista lehmistä yksilöllisesti suoraan peräsuolesta.

Veriplasmasta analysoitiin fosfori-, kalsium ja magnesiumpitoisuudet (mmol/l). Sontanäytteistä määritettiin kuiva-aine- ja fosforipitoisuus $(\mathrm{g} / \mathrm{kg} \mathrm{ka}$ ). Rehunäytteeet kuivattiin ja niistä määritettiin kuivaaine gravimetrisesti sekä raakavalkuainen, raakakuitu ja arviot rehuarvoista (D-arvo, OIV, PVT) NIRanalytiikalla, ja lisäksi analysoitiin kivennäispitoisuudet (Ca, $\mathrm{P}, \mathrm{Mg}, \mathrm{K}, \mathrm{Na}, \mathrm{Cu}, \mathrm{Mn}, \mathrm{Zn}, \mathrm{Fe}$ ).

Lypsykausien 305 päivän maitotuotoksia, veren kivennäispitoisuuksia, toteutuneiden siemennysten määrää tiineyttä kohti ja poikimaväliä verrattiin ryhmien välillä varianssianalyysillä (SPSS). Veren kivennäisten ja siemennyskertojen tapauksessa ennen koetta määritettyjä tietoja (veren 0-näyte ja kokeen ensimmäisen poikimisen siemennystiedot) käytettiin varianssianalyysimallissa mukana kovariaattina. Kaikkien yksilöimättömien sorkkaongelmien ja todettujen tervesorkkaisten eläinten esiintymistä toteutuneissa sorkkahoidoissa tai -tarkastuksissa analysoitiin $\chi^{2}$-riippumattomuustestillä. 


\section{Tulokset ja niiden tarkastelua}

Fosforin kokonaissaanti oli luonnollisesti alempi ryhmällä 1, mutta kuten edellä on oletettu, fosforin saanti karkearehusta, viljasta ja rypsirouheesta riittää nykyisten normien täyttämiseksi (MTT 2004). Myös Valkin ja Beynenin (2003) julkaisemat tuotokseen perustuvat normit $(19 \mathrm{~g}+1,43 \mathrm{~g} / \mathrm{maito}-\mathrm{kg} 600 \mathrm{~kg}: \mathrm{n}$ lehmälle) täyttyvät näin.

Maitotuotoksissa (kunkin kokeen aikana toteutuneen tuotantokauden 305 päivän tuotos) ei ollut merkitseviä eroja ryhmien välillä (Taulukko 1). Hajonta oli varsin huomattavaa ja numeroarvoisten tulosten paremmuus ryhmien välillä vaihteli lypsykaudesta toiseen.

Maidon valkuais- ja rasvapitoisuudet on esitetty Taulukossa 2. Myöskään näissä ei ollut ryhmien välillä systemaattista eroa, vaikkakin joitakin yksittäisiä merkitseviä tai lähes merkitseviä eroja näytti löytyvän (rasva- ja valkuaispitoisuus ensimmäisen tuotoskauden lopulla; $0,01<\mathrm{P}<0,1$ ).

Hedelmällisyyttä kuvaavina muuttujina käytettiin poikimaväliä ja yhtä tiinehtymistä kohti tarvittua siemennyskertojen määrää. Tämänkaltaisissa muuttujissa hajonta on kuitenkin aina huomattavaa, eikä käsittelyjen vaikutuksia olisi yleensäkään helppo saada näkyviin. Tutkimuksen aikana keskimääräiset poikimavälit ryhmittäin vaihtelivat välillä $372-401 \mathrm{~d}$, mutta vaihtelu ei ollut systemaattista, eivätkä erot ryhmien välillä merkitseviä. Poikimavälin pidentymistä tai lyhentymistä kokeen kestäessä ei myöskään todettu kummassakaan ryhmässä. Siemennyskertojen tapauksessa lehmäkohtaisen vaihtelun kontrolloiminen kovariaatin käytöllä edellä kuvatulla tavalla osoittautui perustelluksi (koska kovariaatin vaikutus oli usein merkitsevä, $\mathrm{P}<0,05$ ), ja se todennäköisesti paransi mallin selitysvoimaa, mutta silti selitysasteet olivat matalia, eikä ruokintaryhmien välillä näkynyt merkitseviä eroja tarvittavien siemennyskertojen määrässä (Taulukko 3).

Taulukossa 4 on esitetty kahden sisä- ja ulkoruokintakauden aikana sonnasta otettujen pistenäytteiden fosforipitoisuudet. Pääsääntöisesti fosforipitoisuus on ollut matalampi fosforitonta kivennäistä saaneessa ryhmässä. Erot ovat pieniä, eivätkä ne ole aina merkitseviä $(0,01<\mathrm{P}<0,1)$, ja yhdessä tapauksessa ne ovat epäjohdonmukaisia eli vähemmän fosforia saaneella ryhmällä sonnan fosforipitoisuus on voinut jopa olla korkeampi $(\mathrm{P}<0,05)$. Tässä näkyy todennäköisesti kivennäisfosforin pienehkö merkitys kokonaisfosforin saannissa. Erotuksena useisiin muihin tutkimuksessa määritettyihin muuttujiin sonnan fosforipitoisuuden muutoksille fosforiruokinnan myötä on luonnollisesti selkeä teoriatausta. Märehtijän fosforin saannin noustessa fosforieritys sonnassa lisääntyy jopa lineaarisesti eli imeytyminen riippuu tarpeesta ja saannista (ks. esim. Khorasani ym. 1997). Imeytyminen on kuitenkin ainakin lampailla esim. Scottin ym. (1984) mukaan jossain määrin voinut lisääntyä käyräviivaisesti konsentraation kasvaessa eli imeytymisen lievä lisääntyminen saannin kasvaessa ja vastaavasti ylimäärän erittyminen virtsassa voisi selittää osittain ryhmien välisten erojen pienuutta. Virtsaan erittyneen fosforin määrää ei tässä tutkimuksessa määritetty lainkaan, joten kokonaisfosforieritystä lantaan ei voi täysin arvioida. Vaikka fosforieritys lannassa ei paljon pienentyisikään alemman fosforiruokintatason myötä, alennus puoltaa silti paikkaansa jo kivennäisrehun hinnankin kannalta, mikäli haitallisia vaikutuksia ei esiinny. Lisäksi on syytä huomioida, että fosforikivennäisestä peräisin oleva lannan lisäfosfori voi ilmeisesti olla herkempää huuhtoutumaan kuin kasviperäisistä rehuista peräisin oleva.

Koelehmien pihatto-olosuhteet olivat ilmeisesti varsin herkät tulehduksellisten sorkkavikojen esiintymiselle, ja esiintymislukemat ovat melko korkeita (31\% ryhmässä 1 ja $42 \%$ ryhmässä 2 ). Tähän vaikuttaa osaltaan myös merkitsemistapa eli kaikki sorkkahoitajan käyntikerran yhteydessä havainnoidut lievätkin poikkeavuudet on tilastoitu sorkkavioiksi. Mitään hypoteesia fosforiruokinnan vaikutuksesta asiaan ei kuitenkaan ollut, eikä ryhmien välinen ero ole tilastollisesti merkitsevä.

Veriplasman fosfori- kalsium- ja magnesiumpitoisuudet eri tuotantokausille osuneissa korkean ja matalan tuotoksen kaudella otetuissa näytteissä on esitetty Taulukossa 5. Fosforitasoissa näkyy useimmiten ruokintaryhmän mukainen hyvin pieni ero, mutta sekään ei ole tilastollisesti merkitsevä. Ensimmäisissä välituloksissa havaittiin ensimmäisellä tuotantokaudella ryhmässä 1 korkean tuotoksen näytteissä lievästi, mutta merkitsevästi korkeampi veren magnesiumpitoisuus $(\mathrm{P}<0,05)$, ja tällöin arveltiin fosforiruokintatason mahdollisen vaikutuksen magnesiumaineenvaihduntaan ehkä kaipaavan lisäselvityksiä. Kuitenkin kaikki pitoisuuksissa esiintyvä vaihtelu mahtuu normaaliarvojen sisään. Kun ensimmäisen tuotantokauden havaintoja on tullut myöhemmin kokeeseen mukaan oteltuilta hiehoilta lisää, mainittu ero näyttää poistuneen. Merkittävimpänä vaikuttavana tekijänä havaittuihin pieniin veren kivennäispitoisuuden vaihteluihin näyttää olevan yksilökohtainen vaihtelu, ja ennen koeruokinnan aloittamista otetuissa 0 -näytteissä havaittu pitoisuus näyttää kovarianssianalyysin mukaan jossain määrin 
selittävän varsinkin ensimmäisen tuotantokauden alkupuolen kalsium- ja magnesiumpitoisuuden vaihteluja $(\mathrm{Ca} ; \mathrm{P}<0,1$ ja $\mathrm{Mg} ; \mathrm{P}<0,001)$.

Kokeen aikana luonnollisesti seurattiin myös poikimahalvausten esiintymistä, mutta myös sellaisia muita sairauksia, joilla ei ole teoreettistakaan yhteyttä kivennäisruokintaan. Kuten saattoi odottaakin, tapaukset olivat kuitenkin yksittäisiä eikä niiden jakautumisesta ryhmien välillä voi tehdä johtopäätöksiä (lukuja ei tässä tarpeen esittää). Utareterveyttä seurattiin käyttämällä määrällisenä muuttujana maidon solupitoisuutta. Utaretulehdustapauksia on esiintynyt, myös kroonisen luonteisia Staphylococcus aureus tapauksia, ja solupitoisuudessa näkyy huomattaviakin vaihteluita ja ajoittain korkeahkojakin lukemia (Taulukko 6). Näissäkään erot ruokintakäsittelyjen välillä eivät ole systemaattisia eivätkä tilastollisesti merkitseviä.

\section{Johtopäätökset}

Kolmivuotinen seuranta ei ole osoittanut fosforittomalla kivennäisrehulla olevan mitään merkittävää vaikutusta lypsylehmien tuotokseen, hedelmällisyyteen tai terveyteen. Vaikutus fosforin erittymiseen lannassa jää tutkimuksen perusteella epävarmaksi. Tutkimusasetelma on hypoteesien asettamisen ja niiden tilastollisen testaamisen kannalta ollut jossain määrin ongelmallinen, koska teorian valossa eroja tuotantoja terveysmuuttujissa ei oikeastaan ole ollut odotettavissakaan. Tutkimuksen tulokset sinänsä tukevat tätä. Kaiken kaikkiaan voidaan siis pitää todennäköisenä, että sekä ympäristö-, taloudellisuus-, tuotos- että terveysnäkökohdat huomioituna fosforilisän poistaminen kivennäisrehuista on perusteltua ainakin kokeessa käytetyn kaltaisella ruokinnalla.

\section{Kirjallisuus}

Huhtanen, P., Nousiainen, J. \& Rinne, M. 2006. Recent developments in forage evaluation with special reference to practical applications. Agric. Food Sci. 15: 293-323.

Khorasani, G.R., Janzen, R.A., McGill, W.B. \& Kennelly, J.J. 1997. Site and extent of mineral absorption in lactating cows fed whole-crop cereal grain silage or alfalfa silage. J. Anim. Sci. 75: 239-348.

MTT 2004. Rehutaulukot ja ruokintasuositukset 2004 märehtijät - siat - siipikarja - turkiseläimet - hevoset. MTT:n selvityksiä 86.82 p.

Scott, D., McLean, A.F. \& Buchan, W. 1984. The effect of variation in phosphorus intake on net intestinal phosphorus absorption, salivary phosphorus secretion and pathway of excretion in sheep fed roughage diets. Quart. J. Exp. Physiol. 69: 438-452.

Tuori, M., Kaustell, K., Valaja, J., Aimonen, E., Saarisalo, E. \& Huhtanen, P. 1996. Rehutaulukot ja ruokintasuositukset. Märehtijät - siat - siipikarja - turkiseläimet - hevoset. 99 p. Yliopistopaino, Helsinki.

Valk, H. \& Beynen, A.C. 2003. Proposal for the assessment of phosphorus requirements of dairy cows. Livest. Prod. Sci. 79: 267-272.

Wu, Z., Satter, L.D., Blohowiak, A.J., Stauffacher, R.H. \& Wilson, J.H. 2001. Milk production, estimated phosphorus excretion and bone characteristics of dairy cows fed different amounts of phosphorus for two or three years. J. Dairy Sci. 84: 1738-1748.

Yrjänen, S., Nousiainen, J.I., Kytölä, K., Khalili, H. \& Huhtanen, P. 2003. Ruokinnalliset mahdollisuudet parantaa fosforin hyväksikäyttöä maidontuotannossa. In: J. Uusi-Kämppä, M. Yli-Halla ja K. Grék (toim.). Lypsykarjataloudesta tulevan ympäristökuormituksen vähentäminen. Maa- ja elintarviketalous 25: s. 13-25. verkkojulkaisu: http://www.mtt.fi/met/pdf/met25.pdf 
Taulukko 1. Maitotuotos ryhmittäin (kg/305 pv) kolmella tuotoskaudella.

\begin{tabular}{|cccccccc|}
\hline & \multicolumn{3}{c}{ Ryhmä 1 } & \multicolumn{3}{c|}{ Ryhmä 2 } & P ryhmä \\
& $\mathrm{kg}$ & $\mathrm{n}$ & SEM & $\mathrm{kg}$ & $\mathrm{n}$ & SEM & \\
1. tuotoskausi & 6727 & 18 & 261 & 6419 & 17 & 227 & \\
2. tuotoskausi & 7494 & 15 & 302 & 7462 & 14 & 323 & \\
3. tuotoskausi & 7576 & 6 & 367 & 7143 & 8 & 655 & \\
\hline
\end{tabular}

Taulukko 2. Maidon valkuais- ja rasvapitosisuus (\%) kolmella tuotoskaudella.

\begin{tabular}{|lccccc|}
\hline & Ryhmä 1 & SEM & Ryhmä 2 & SEM & P $_{\text {ryhmä }}$ \\
Valkuainen, 1. tuotoskausi, alku & 3,37 & 0,05 & 3,29 & 0,04 & \\
Valkuainen, 1. tuotoskausi, loppu & 3,87 & 0,07 & 3,64 & 0,06 & $*$ \\
Valkuainen, 2. tuotoskausi, alku & 3,41 & 0,07 & 3,32 & 0,07 & \\
Valkuainen, 2. tuotoskausi, loppu & 3,83 & 0,07 & 3,76 & 0,08 & \\
Valkuainen, 3. tuotoskausi, alku & 3,41 & 0,07 & 3,3 & 0,07 & \\
Valkuainen, 3. tuotoskausi, loppu & 3,82 & 0,13 & 3,83 & 0,14 & \\
Rasva, 1. tuotoskausi, alku & 4,85 & 0,12 & 4,66 & 0,09 & \\
Rasva, 1. tuotoskausi, loppu & 5,14 & 0,13 & 4,83 & 0,11 & o \\
Rasva, 2. tuotoskausi, alku & 4,74 & 0,12 & 4,61 & 0,13 & \\
Rasva, 2. tuotoskausi, loppu & 5,11 & 0,18 & 4,91 & 0,22 & \\
Rasva, 3. tuotoskausi, alku & 4,67 & 0,25 & 4,82 & 0,19 & \\
Rasva, 3. tuotoskausi, loppu & 4,97 & 0,31 & 4,88 & 0,15 & \\
\hline
\end{tabular}

Taulukko 3. Tiinehtymistä kohti tarvittujen siemennyskertojen määrä kolmen vuosikierron aikana.

\begin{tabular}{|lcccccccc|} 
& Ryhmä 1 & $\mathrm{n}$ & $\mathrm{SEM}( \pm)$ & Ryhmä 2 & $\mathrm{n}$ & $\mathrm{SEM}( \pm)$ & $\mathrm{P}_{\text {ryhmä }}$ & $\mathrm{P}_{\mathrm{a}}{ }^{1}$ \\
2. poikiminen & 3,1 & 19 & 0,40 & 2,3 & 19 & 0,40 & & \\
3. poikiminen & 2,1 & 15 & 0,55 & 3,4 & 14 & 0,57 & & \\
4. poikiminen & 1,8 & 6 & 0,59 & 2,8 & 11 & 0,42 & & ** \\
\hline
\end{tabular}

1. mallissa mukana kovariaattina tarvittujen siemennyskertojen määrä ennen kokeeseen tuloa eli poikimisessa ennen kokeen ensimmäsistä tuotoskautta; a=kovariaatille estimoitu lineaarinen regressiokerroin

Taulukko 4. Sonnan kuiva-aineen fosforipitoisuus näytteenottoajankohtina, g/kg KA.

\begin{tabular}{|cccccccc|}
\hline & \multicolumn{3}{c}{ Ryhmä 1 } & \multicolumn{5}{c|}{ Ryhmä 2 } & $P_{\text {ryhmä }}$ \\
& g/kg KA & $\mathrm{n}$ & $\mathrm{SEM}( \pm)$ & $\mathrm{g} / \mathrm{kg} \mathrm{KA}$ & $\mathrm{n}$ & $\mathrm{SEM}( \pm)$ & \\
Sisäruokinta 2005 & 7,4 & 15 & 0,23 & 8,3 & 17 & 0,22 & * \\
Laidunkausi 2005 & 13,6 & 13 & 0,81 & 11,6 & 15 & 0,51 & * \\
Sisäruokinta 2006 & 9,3 & 11 & 0,53 & 10,5 & 15 & 0,33 & 0 \\
Laidunkausi 2006 & 7,0 & 10 & 0,41 & 8,5 & 14 & 0,48 & * \\
\hline
\end{tabular}


Taulukko 5. Veriplasman kivennäispitoisuudet korkean ja matalan tuotannon vaiheissa eri tuotantokausilla, mmol/1.

\begin{tabular}{|c|c|c|c|c|c|c|c|c|}
\hline & \multicolumn{3}{|c|}{ Ryhmä 1} & \multicolumn{3}{|c|}{ Ryhmä 2} & \multirow[t]{3}{*}{$\mathrm{P}_{\text {ryhmä }}{ }^{1}$} & \multirow[t]{3}{*}{$\mathrm{P}_{\mathrm{a}}{ }^{1}$} \\
\hline & $\mathrm{mmol} / \mathrm{l}$ & $\mathrm{n}$ & $\operatorname{SEM}( \pm)$ & $\mathrm{mmol} / /$ & $\mathrm{n}$ & $\operatorname{SEM}( \pm)$ & & \\
\hline 1. tuotoskausi & & 19 & & & 22 & & & \\
\hline Ca_korkea & 2,53 & & 0,028 & 2,53 & & 0,026 & & 0 \\
\hline Ca_matala & 2,58 & & 0,029 & 2,58 & & 0,026 & & \\
\hline P_k̄orkea & 1,53 & & 0,073 & 1,58 & & 0,068 & & \\
\hline P_matala & 1,57 & & 0,09 & 1,51 & & 0,081 & & \\
\hline Mg_korkea & 1,27 & & 0,038 & 1,23 & & 0,035 & & $* \star *$ \\
\hline Mg_matala & 1,27 & & 0,096 & 1,32 & & 0,087 & & \\
\hline 2. tuotoskausi & & 17 & & & 16 & & & \\
\hline Ca_korkea & 2,57 & & 0,025 & 2,61 & & 0,049 & & \\
\hline Ca_matala & 2,57 & & 0,031 & 2,57 & & 0,049 & & \\
\hline P_k̄orkea & 1,33 & & 0,067 & 1,38 & & 0,063 & & \\
\hline P_matala & 1,27 & & 0,052 & 1,4 & & 0,107 & & \\
\hline Mg_korkea & 1,36 & & 0,061 & 1,44 & & 0,082 & & \\
\hline Mg_matala & 1,79 & & 0,13 & 1,52 & & 0,149 & & \\
\hline 3. tuotoskausi & & 12 & & & 11 & & & \\
\hline Ca_korkea & 2,57 & & 0,049 & 2,67 & & 0,049 & & \\
\hline Ca_matala & 2,57 & & 0,039 & 2,64 & & 0,044 & & \\
\hline P_k̄orkea & 1,3 & & 0,145 & 1,39 & & 0,091 & & \\
\hline P_matala & 1,36 & & 0,121 & 1,59 & & 0,164 & & \\
\hline Mg_korkea & 1,22 & & 0,076 & 1,1 & & 0,070 & & \\
\hline Mg_matala & 1,17 & & 0,037 & 1,16 & & 0,050 & & \\
\hline
\end{tabular}

Taulukko 6. Maidon solupitoisuus korkean ja matalan tuotannon vaiheissa kolmella tuotoskaudella (1000 kpl/ml).

\begin{tabular}{|lccccc|}
\hline & Ryhmä 1 & SEM & Ryhmä 2 & SEM & P $_{\text {ryhmä }}$ \\
1. tuotoskausi, alku & 106 & 27 & 75 & 17 & \\
1. tuotoskausi, loppu & 168 & 76 & 106 & 25 & \\
2. tuotoskausi, alku & 132 & 35 & 81 & 11 & \\
2. tuotoskausi, loppu & 247 & 58 & 125 & 20 & 0 \\
3. tuotoskausi, alku & 220 & 74 & 317 & 100 & \\
3. tuotoskausi, loppu & 201 & 85 & 133 & 30 & \\
\hline
\end{tabular}

